\title{
Regulation of T Cell Trafficking by Enzymatic Synthesis of O-Glycans
}

\author{
Samuel J. Hobbs ${ }^{1}$ and Jeffrey C. Nolz ${ }^{1,2,3 *}$ \\ ${ }^{1}$ Department of Molecular Microbiology and Immunology, Oregon Health and Science University, Portland, OR, \\ United States, ${ }^{2}$ Department of Cell, Developmental and Cancer Biology, Oregon Health and Science University, \\ Portland, OR, United States, ${ }^{3}$ Department of Radiation Medicine, Oregon Health and Science University, Portland, OR, \\ United States
}

Selectins constitute a family of oligosaccharide binding proteins that play critical roles in regulating the trafficking of leukocytes. In T cells, L-selectin (CD62L) controls the capacity for naive and memory $T$ cells to actively survey peripheral lymph nodes, whereas $P$ - and E-selectin capture activated T cells on inflamed vascular endothelium to initiate extravasation into non-lymphoid tissues. The capacity for $T$ cells to interact with all of these selectins is dependent on the enzymatic synthesis of complex O-glycans, and thus, this protein modification plays an indispensable role in regulating the distribution and homing of both naive and previously activated T cells in vivo. In contrast to neutrophils, O-glycan synthesis is highly dynamic in T cell populations and is largely controlled by extracellular stimuli such as antigen recognition or signaling though cytokine receptors. Herein, we review the basic principles of enzymatic synthesis of complex O-glycans, discuss tools and reagents for studying this type of protein modification and highlight our current understanding of how O-glycan synthesis is regulated and subsequently impacts the trafficking potential of diverse T cell populations.

Keywords: T cell trafficking, O-glycans, selectins, high endothelial venules, T cell memory, sialyl Lewis X, PSGL-1, inflammation

\section{INTRODUCTION}

Protein glycosylation occurs through the collective action of glycosyltransferases and glycosidases that are active in the lumen of the endoplasmic reticulum or the golgi complex. This protein modification has been shown to impact a variety of immunological processes, including lymphocyte development, trafficking, apoptosis, antigen recognition, and cellular response to cytokines (1). The number of possible, unique glycan modifications is vast and largely not understood, but can be generalized into two broad categories based on the amino acid from which the glycan modification originates. $\mathrm{N}$-linked glycosylation is the most common form of glycosylation, is initiated from an asparagine residue through a $\beta-\mathrm{N}$ glycosidic bond, and is always found in the context of an NXT/S motif. In contrast, O-linked glycans do not require a bona fide consensus motif and are covalently attached to the oxygen atom from the hydroxyl group of serine or threonine amino acids. Among the many diverse functions for O-glycans in regulating many aspects of $\mathrm{T}$ cell biology, the most characterized role for these post-translational modifications is for capturing circulating $\mathrm{T}$ cells on vascular endothelium and allowing them to infiltrate both lymphoid and non-lymphoid tissues $(2,3)$.

\section{SELECTINS AND SELECTIN LIGANDS}

Selectins are a family of C-type lectin domain containing proteins that bind specific carbohydrate structures in a calcium-dependent manner (4). These proteins are responsible for the initial 
capture (i.e., "rolling") of leukocytes from the circulation before extravasation across the vascular endothelium can occur. Each selectin is named according to its expression pattern. E-selectin (CD62E) is expressed on endothelial cells and P-selectin (CD62P) is stored in $\alpha$-granules in platelets (as well as Weibel-Palade bodies in endothelial cells). Following infection or tissue injury, both $\mathrm{P}$ - and E-selectin are expressed by the vascular endothelium in response to inflammatory cytokines such as IL- 1 and TNF $\alpha$ (5). In contrast, L-selectin (CD62L) is constitutively expressed on many leukocytes. All of the selectins share a common general structure that consists of an amino-terminal lectin domain that is responsible for ligand binding, an epidermal growth factorlike domain, a variable number of consensus repeats, a transmembrane domain, and a cytoplasmic domain (6).

Selectin ligands can be divided into two functional categories-those that have a role in steady-state lymphocyte homing to secondary lymphoid organs and those that have a role in the capture of leukocytes in response to inflammation or tissue injury. Lymphocyte homing to lymph nodes is primarily mediated by CD62L ligands that are constitutively expressed by endothelial cells in high endothelial venules (HEVs), while leukocyte homing into non-lymphoid tissue is mediated largely by P-and E-selectin ligands $(7,8)$. Several proteins have been demonstrated to bind
CD62L and mediate steady-state lymphocyte homing into lymph nodes including GlyCAM-1, CD34, spg200, podocalyxin, and endomucin (3), and, based on the O-glycans they are decorated with, are collectively referred to as peripheral node addressins (PNAd). P-selectin glycoprotein ligand-1 (PSGL-1) is the primary ligand for P-selectin and can also bind to both L- and E-selectin (9). Recently, the T cell immunoglobulin and mucin domain glycoprotein 1 has also been shown to bind P-selectin, when expressed by $\mathrm{CD}^{+} \mathrm{T}$ cells (10). Several other leukocyteexpressed proteins besides PSGL-1 are capable of binding E-selectin, including E-selectin ligand-1 (ESL-1), CD44, and CD43 (11). In all cases, the unmodified selectin ligand is unable to bind to selectins, rather this interaction is dependent on the presence of specific $\mathrm{O}$-linked glycosylation modifications.

\section{ENZYMATIC SYNTHESIS OF O-GLYCANS}

Synthesis of O-glycans is initiated by the attachment of $\mathrm{N}$-acetylgalactosamine (GalNAc) to the oxygen molecule of the hydroxyl group present on serine or threonine amino acids. From there, O-glycans can contain a wide variety of modifications, but the most common are those which contain one of four core structures branching from the initial GalNAc (Figure 1; Table 1). Of

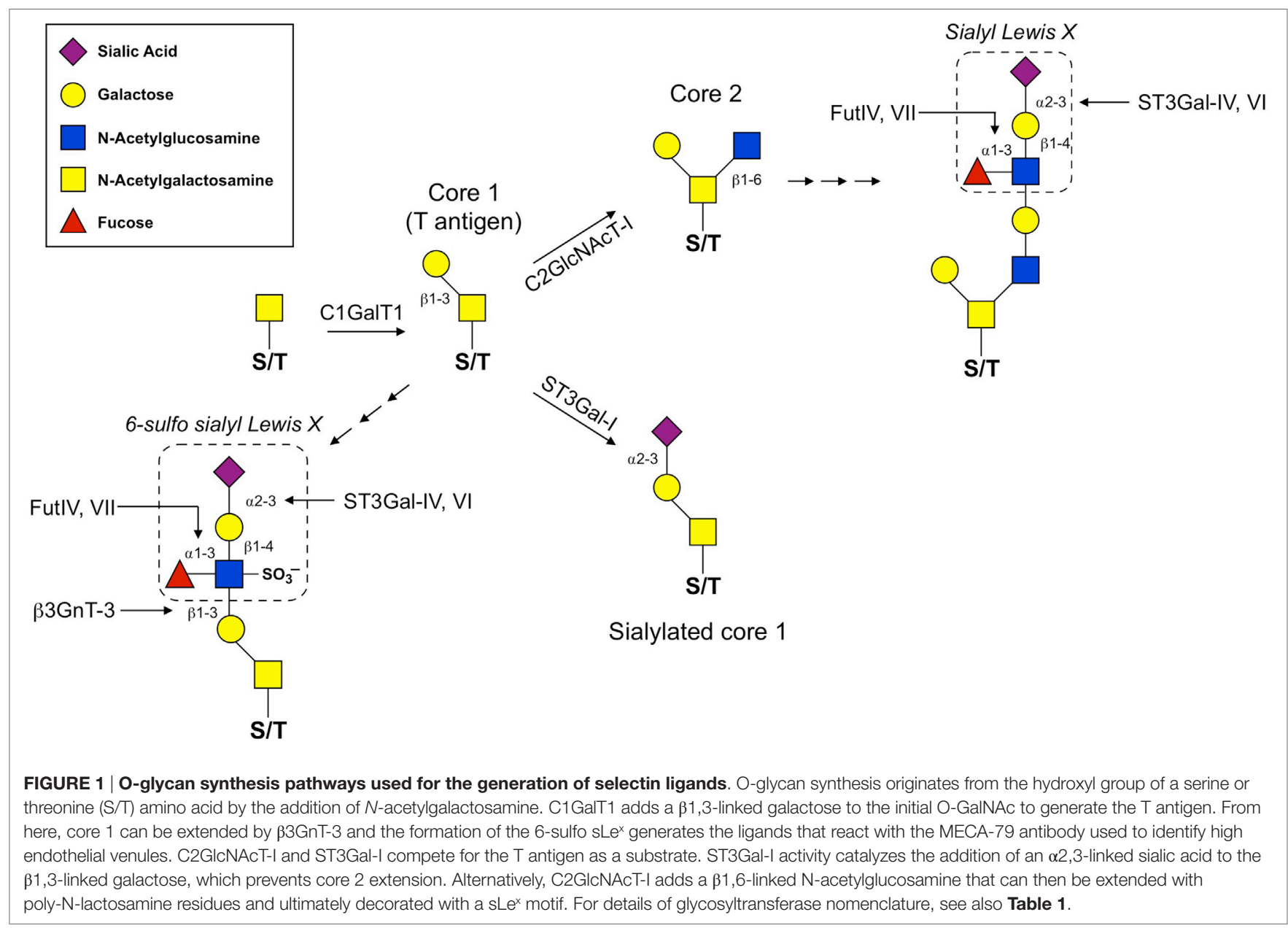


TABLE 1 | Mice with gene-targeted deficiencies for enzymes involved in the synthesis of O-glycans.

\begin{tabular}{|c|c|c|c|c|}
\hline Gene & Full enzyme name & Abbreviated name(s) & Function & Reference \\
\hline Gent1a & Core 2 $\beta 1-6 N$-acetylglucosaminyltransferase-| & C2GlcNAcT-I; C2GnT-I & Initial $\beta 1-6$ GlcNAc for core 2 O-glycans & Ellies et al. (15) \\
\hline Fut7 & $\alpha 1-3$ fucosyltransferase VII & FutVII; FucTVII & Fucosyltransferase for Lewis X synthesis (Major) & Maly et al. (16) \\
\hline Fut4 & $\alpha 1-3$ fucosyltransferase IV & FutIV; FucTIV & Fucosyltransferase for Lewis X synthesis (Minor) & Homeister et al. (17) \\
\hline St3gal4 & ST3 $\beta$-galactoside $\alpha 2-3$ sialyltransferase IV & ST3Gal-IV & Sialylation of Lewis X (Major) & Ellies et al. (18) \\
\hline St3gal6 & ST3 $\beta$-galactoside $\alpha 2-3$ sialyltransferase VI & ST3Gal-VI & Sialylation of Lewis X (Minor) & Yang et al. (19) \\
\hline B3Gnt3 & $\beta 1-3 N$-acetylglucosaminyltransferase-3 & $\beta 3 G n T-3$ & Extension of Core $1 \mathrm{O}$-glycans & Yeh et al. (20) \\
\hline St3Gal1a & ST3 $\beta$-galactoside $\alpha 2-3$ sialyltransferase-I & ST3Gal-I & Core 1 sialylation & Priatel et al. (21) \\
\hline
\end{tabular}

aMice with conditional potential available.

these four core structures, core 1 and core 2 have been implicated in a variety of immunological processes, including $\mathrm{T}$ cell contraction by apoptosis, antibody function, antigen receptor activation, and cell adhesion and trafficking (12-14). On the other hand, the formation of core 3 and core 4 structures is far less prevalent and no clear role for these O-glycan types have been shown to contribute significantly to the regulation of innate or adaptive immunity.

The diversity of O-glycan structures is achieved through the activity of glycosyltransferase enzymes that catalyze the addition of monosaccharides in a sequential, stepwise fashion (Figure 1). The expression of these enzymes is generally regulated at the transcriptional level and is often cell-type and tissue specific (22). To generate a core $1 \mathrm{O}$-glycan, core $1 \beta 1$-3 galactosyltransferase (C1GalT1) adds a galactose to the initial GalNAc in a $\beta 1-3$ linkage. The resulting unmodified core 1 structure is also referred to as the $\mathrm{T}$ antigen and is rarely left unmodified. The potential modifications that can be added to the $\mathrm{T}$ antigen are extension, capping, or it can be used as a substrate for synthesis of core 2 O-glycans. Capping of core 1 with $\alpha 2,3$-linked sialic acid requires ST3Gall in T cells and this modification inhibits the synthesis of core $2 \mathrm{O}$-glycans (23). Mechanistically, this is because core $2 \beta 1-6$ $\mathrm{N}$-acetylglucosaminyltransferase (C2GlcNAcT), the enzyme responsible for core 2 synthesis, requires unmodified core 1 as a substrate and catalyzes the addition of an $\mathrm{N}$-acetylglucosamine (GlcNAc) to unmodified core 1 via a $\beta 1-6$ linkage. There are three enzymes in the C2GlcNAcT family, C2GlcNAcT-I, -II, and -III, which are transcribed from the genes Gcnt1, Gcnt3, and Gcnt4, respectively. (Note: Gcnt2 is an $\mathrm{N}$-acetylglucosaminyltransferase but does not exhibit core 2 activity.)

Extension of both core 1 and core 2 is catalyzed by $\mathrm{N}$-acetylglucosaminyltransferases and galactosyltransferases, which add repeated units of $\mathrm{N}$-acetyllactosamine to the galactose of core 1 or the GlcNAc of core 2. Poly- $N$-acetyllactosamine repeats are more commonly found on core $2 \mathrm{O}$-glycans and can serve as acceptor sites for further modifications. One such modification that is critical for selectin ligand formation is the addition of the tetrasaccharide Lewis $\mathrm{X}\left(\mathrm{Le}^{\mathrm{x}}\right)$ to extended core $2 \mathrm{O}$-glycans. The most basic form of the Le $\mathrm{e}^{\mathrm{x}}$ antigen consists of a fucose bound to the $N$-acetyllatosamine of the $\mathrm{Le}^{\mathrm{x}}$ by an $\alpha 1-3$ linkage. There are a diverse set of more complex Lewis antigens utilized throughout biology, but within the scope of those that impact selectin binding, two forms are the most relevant. First, P- and E-selectin ligands have a sialyl Lewis $\mathrm{X}\left(\mathrm{sLe}^{\mathrm{x}}\right)$ which contains a sialic acid bound to the terminal galactose of the Lewis antigen in an $\alpha 2-3$ linkage, catalyzed by the $\alpha 2-3$ sialyltransferases (ST3Gal) family of enzymes (18). The other form is a sulfated version (6-sulfo $\left.s L e^{x}\right)$, which contains a sulfate attached to C6 of the GlcNAc of the Lewis antigen and is present on PNAd (CD62L ligands). Thus, terminal sialic acids and fucoses (as well as GlcNAc sulfation) that are attached to the poly- $N$-acetyllactosamine repeats of complex $\mathrm{O}$-glycans are critical for generating the functional binding motif for all selectins.

\section{TOOLS FOR INTERROGATING O-LINKED GLYCOSYLATION}

The ability to identify specific glycan structures is paramount to understanding and investigating the role of glycans in biology. To this end, lectins and monoclonal antibodies can be used in glycan analysis, at both the cellular and protein level. Lectins are a class of proteins (typically isolated from plants) that bind general features of carbohydrates (e.g., specific linkages between two monosaccharides), but typically cannot identify highly specific or complex glycan determinants. The identification of a specific complex, protein-associated glycan requires a monoclonal antibody $(\mathrm{mAb})$, but these reagents are difficult to generate and are less available than lectins (24). Finally, the use of glycosidases can be used to cleave specific glycosidic bonds and allow one to assess functional roles for saccharides. For example, the presence of sialic acid on $s L e^{x}$ is critical for selectin binding, as rolling of leukocytes and the generation of P- and E-selectin ligands is greatly diminished after treatment with neuraminidase (25). Ultimately, however, the generation of gene-deficient animals is required to designate meaningful biological functions to individual glycosyltransferases that regulate the trafficking of T cells during both homeostasis or infections/ inflammation (Table 1).

Fluorescently labeled lectins and antibodies can be used in flow cytometry or imaging to determine the expression and distribution of glycan patterns in cells or in tissue, but their utility extends beyond these applications. Lectins covalently linked to agarose can also be used in affinity purification of a protein or cell of interest. As lectins are typically isolated from plant seeds, they are generally cheaper than mAbs and are therefore well suited for purification applications. The lectins phytohemagluttinin from Phaseolus vulgaris and Concanavalin A (ConA) bind to complex $\mathrm{N}$-glycans and can be used as potent mitogens for expanding and/ or activating $\mathrm{T}$ cells in vitro. 
There are a large number of commercially available lectins and their binding specificities cover a wide range of glycan determinants. For example, Erythrinia cristagalli lectin binds to Gal $\beta 1-\mathrm{R}$ (terminal galactose) structures, whereas tomato (LEL) and potato (STL) lectins bind to poly- $N$-acetyllactosamine repeats, generated on either $\mathrm{N}$ - or O-glycans. Aleuria aurantia lectin binds terminal fucoses such as the $\alpha 1,3$-linkage found in $\mathrm{sLe}^{\mathrm{x}}$, but reportedly has the highest affinity for $\alpha 1,6$-linked fucose (26), a feature of many complex N-glycans. Although they are typically specific for only short or even individual saccharide motifs, the wide range of determinants covered by lectins allows them to be used in combination to reveal specific glycan structures. For example, a combination of Jacalin, peanut agglutinin (PNA), and Maackia amurensis lectin II (MAL II) can be used to determine the sialylation state of core $1 \mathrm{O}$-glycans on a cell surface or protein. Jacalin will bind the $\mathrm{T}$ antigen whether or not is sialylated, while PNA will only bind the unsialylated T antigen (Figure 2). Conversely, MAL II is specific for the $\alpha 2,3$-linked sialic acid attached to the core $1 \beta 1,3$-galactose (27). Thus, a loss of Mal II binding, a gain in PNA binding and no change in Jacalin binding would collectively indicate an increase of unsialylated core 1 O-glycans.

The development of monoclonal antibodies that are able to recognize specific glycan motifs on individual proteins has not been rigorously pursued. However, several $\mathrm{mAb}$ specific for each of the selectins (both for human and mice) have been generated that can be used to analyze expression and to functionally inhibit receptor-ligand interactions in vitro and in vivo (Table 2). In addition to antibodies against selectins, there are some antibodies that recognize glycosylation patterns on proteins. The ligand for the HECA-452 mAb is "cutaneous lymphocyte antigen" (CLA), which is often used in human samples to identify $\mathrm{T}$ cells that can bind to E-selectin and have "skin homing potential" $(28,29)$. MECA-79 is a mAb that reacts to 6-sulfo Le $\mathrm{e}^{\mathrm{x}}$ on core $1 \mathrm{O}$-glycans and is used to identify HEVs (or HEV-like structures) and this antibody can sufficiently block naive $\mathrm{T}$ cell homing to secondary lymphoid organs in vivo (30). Finally, the mAb 1B11 binds mouse CD43 only when modified with core $2 \mathrm{O}$-glycans (31). In fact, in T cells, $1 \mathrm{~B} 11$ reactivity has been shown to require Gcnt1, the enzyme responsible for the initiation of core $2 \mathrm{O}$-glycan synthesis (32).

\section{DYNAMIC O-GLYCAN SYNTHESIS REGULATES THE TRAFFICKING OF T CELLS}

In contrast to cells of the innate immune system (e.g., neutrophils and monocytes), which often constitutively express the collection of enzymes that generate selectin ligands on their cell surface, the synthesis of core $2 \mathrm{O}$-glycans and the expression of CD62L in T cells is highly dynamic. As mentioned previously, the regulation of glycosyltransferase functional activity is believed to occur largely at the transcriptional level, where the enhancement (or inhibition) of enzyme expression generally controls the surface glycan landscape of a cell. Thus, the signaling mechanisms that ultimately impact the transcriptional

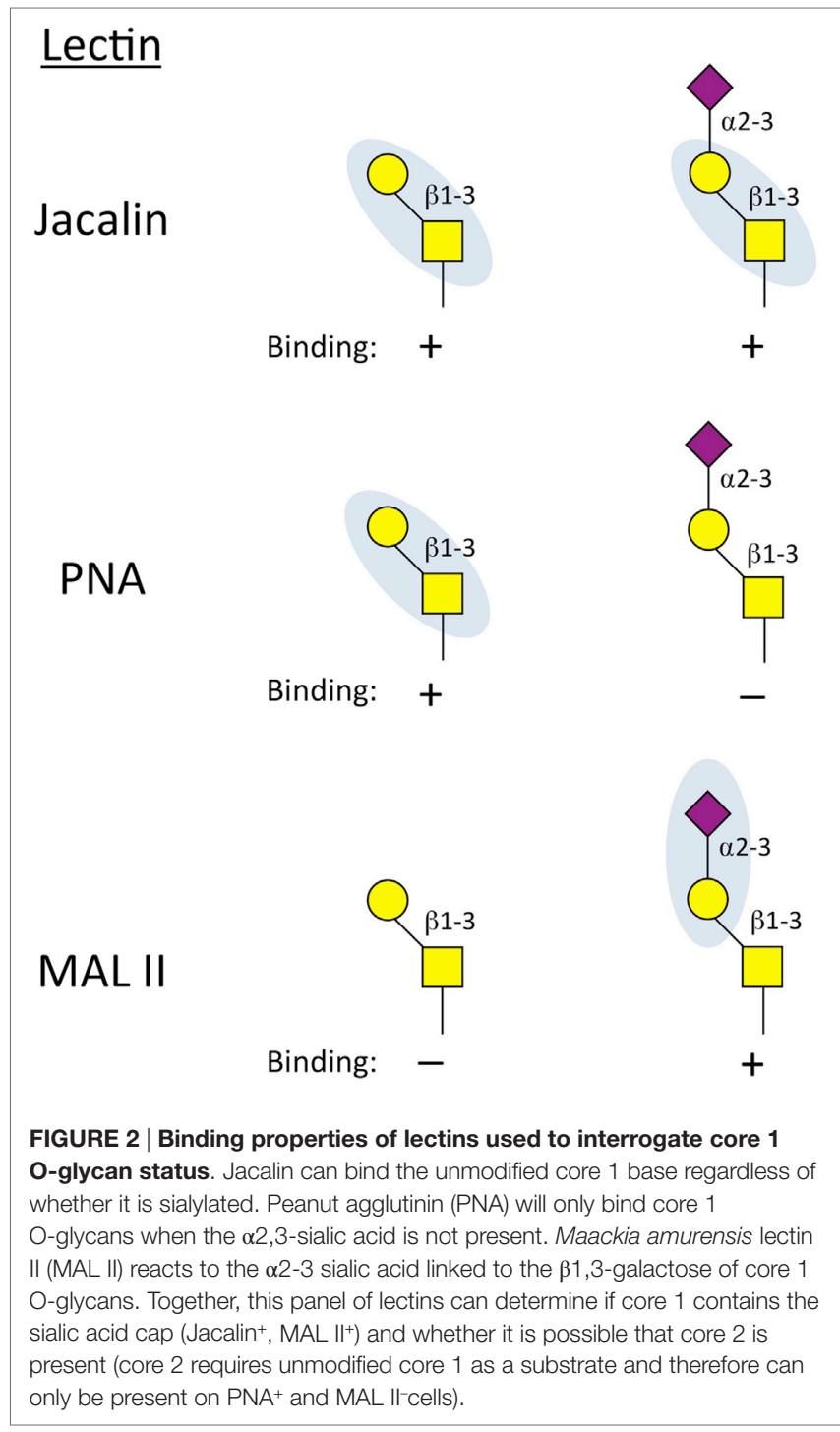

TABLE 2 | Examples of monoclonal antibodies for studying O-glycosylation and selectin-mediated trafficking in mice.

\begin{tabular}{lll}
\hline Target & Clone & Reference \\
\hline L-selectin (CD62L) & MEL-14 & Gallatin et al. (33) \\
P-Selectin (CD62P) & RB40.34 & Bosse and Vestweber (34) \\
E-Selectin (CD62E) & $10 E 9.6$ & Ramos et al. (35) \\
E-Selectin (CD62E) & 9A9 & Norton et al. (36) \\
PSGL-1 & 4RA10 & Frenette et al. (37) \\
PSGL-1 & 2PH1 & Borges et al. (38) \\
O-Glycosylated CD43 & 1B11 & Jones et al. (39) \\
PNAd (sulfated core 1 O-glycans) & MECA-79 & Streeter et al. (30) \\
\hline
\end{tabular}

${ }^{a} 1 B 11$ will also bind to an unsialylated form of CD45.

and/or epigenetic regulation of glycosyltransferase expression in both $\mathrm{T}$ cells and endothelial cell populations is critical for the overall understanding of how specific $\mathrm{T}$ cell populations are able to traffic into both lymphoid and non-lymphoid tissues (40). 


\section{RECRUITMENT OF T CELL PRECURSORS INTO THE THYMUS}

Before they can populate the periphery, hematopoietically derived $\mathrm{T}$ cell precursors exit the bone marrow and must home to the thymus to undergo positive and negative selection to mature into either a $\mathrm{CD}^{+}$or $\mathrm{CD} 4^{+} \mathrm{T}$ cell. Interestingly, thymic endothelial cells express P-selectin and the ability for $\mathrm{T}$ cell precursors to generate $\mathrm{P}$-selectin ligands is critical for allowing these cells to home to the thymus (41). Parabiotic experiments that combined the circulation of either Gcnt1, PSGL-1, or P-selectin deficient mice with wild-type (WT) mice revealed that WT T cell precursors were able to populate Gcnt1- and PSGL-1-deficient thymuses, but not thymuses that lacked P-selectin. Conversely, $\mathrm{P}$-selectin deficient $\mathrm{T}$ cell precursors were able to populate thymuses independent of thymically expressed Gcnt1 and PSGL-1. Thus, this eloquent study demonstrated that Gcnt1-dependent modification of PSGL-1 on T cell precursors generates a ligand that can bind thymic endothelial P-selectin that is required for their homing to the thymus.

\section{TRAFFICKING OF T CELLS INTO LYMPH NODES}

Following their development and exit from the thymus, antigennaive $\mathrm{T}$ cells enter the periphery where they continually survey the spleen and secondary lymphoid organs for an encounter with cognate antigen. Naive T cells express high levels of CD62L and, in fact, are typically defined as being CD $44^{\mathrm{Lo}} / \mathrm{CD} 62 \mathrm{~L}^{\mathrm{Hi}}$ in mice and $\mathrm{CD} 45 \mathrm{RA}^{+} / \mathrm{CD} 62 \mathrm{~L}^{\mathrm{Hi}}$ in humans. Once a naive $\mathrm{T}$ cell is activated by antigen, co-stimulation, and inflammatory cytokines, a rapid proliferative burst gives rise to clonally expanded effector $\mathrm{T}$ cells that gain effector functions (e.g., cytotoxicity, cytokine production) and lose expression of CD62L by suppressed transcriptional activity and protease-mediated cleavage $(42,43)$. Most effector $\mathrm{T}$ cells have a limited life span and are eliminated by apoptosis during the contraction phase of the response, but $5-10 \%$ of these cells survive to become the long-lived memory $\mathrm{T}$ cell population $(44,45)$.

Expression of CD62L, along with the chemokine receptor CCR7, categorizes memory $\mathrm{T}$ cells into either the central $\left(\mathrm{T}_{\mathrm{CM}}\right)$ or effector $\left(\mathrm{T}_{\mathrm{EM}}\right)$ memory subsets in both humans and mice $(46,47)$. $\mathrm{T}_{\mathrm{CM}}$ express $\mathrm{CD} 62 \mathrm{~L}$ and actively survey lymph nodes, whereas $\mathrm{T}_{\mathrm{EM}}$ do not express CD62L and their distribution is therefore limited to the circulation, spleen, and non-lymphoid tissues. This distribution of trafficking potential within the memory $\mathrm{T}$ cell compartment has been postulated to maximize the tissue surveillance of these protective $T$ cells, so that both lymph nodes and peripheral tissues can be patrolled for invading pathogens. In fact, $\mathrm{CD} 62 \mathrm{~L}^{-/-}$memory $\mathrm{CD} 8^{+} \mathrm{T}$ cells are unable to provide protective immunity against chronic viral infection in lymph nodes, but provide complete protection against Listeria monocytogenes infection of the spleen and liver (48). Thus, there is utility in using CD62L expression to identify $T$ cells subsets and also demonstrates the functional importance of this gene in regulating the distribution of memory $\mathrm{T}$ cell populations in vivo.
Naive and $\mathrm{T}_{\mathrm{CM}} \mathrm{T}$ cells exit the circulation and enter lymph nodes by crossing specialized vascular endothelium known HEVs. PNAd are the functional ligands for CD62L expressed by the HEV and rely on the synthesis of sulfated core $1 \mathrm{O}$-glycans on proteins such as GlyCAM and CD34. The complete gene expression profile of HEV endothelial cells isolated from peripheral lymph nodes has now been reported (49). As expected, the cells express enzymes that stimulate O-glycan synthesis including C1GalT1, Gcnt1, B3Gnt3, Fut7, and several B4GalTs, all which could contribute to the biosynthesis of CD62L ligands. Interestingly, studies aimed to identify a requirement for individual glycosyltransferases in generating CD62L ligands for T cell trafficking across HEVs have been less clear. $\beta 3 \mathrm{GnT}-3$ is required for extending core $1 \mathrm{O}$-glycans and HEVs in $\mathrm{B} 3 \mathrm{Gnt} 3^{-/-}$mice lose reactivity to the MECA-79 antibody (20). Furthermore, HEVs from mice deficient in both B3Gnt3 and Gcnt1 lose essentially all extended O-glycans (both core 1 and core 2), but surprisingly, naive $\mathrm{T}$ cell trafficking into peripheral lymph nodes is reduced by only $\sim 50 \%$ (50). However, because naive $\mathrm{T}$ cell trafficking into lymph nodes is CD62L-dependent, it was found that CD62L ligands could also be formed on complex N-glycans. In contrast, the $\alpha 1,3$-fucosyltransferases Fut7/Fut 4 and the $\mathrm{N}$-acetylglucosamine-6-O-sulfotransferases GlcNAc6ST-1/-2 are more essential for naive $\mathrm{T}$ cell homing into lymph nodes $(16,17$, 51-53), thereby demonstrating that the formation of 6-sulfo sLe $\mathrm{e}^{\mathrm{x}}$ is critical, but can be synthesized on both $\mathrm{O}$ - and N-glycans. Overall, these findings suggest that there are several redundant glycosylation mechanisms that can ultimately recruit CD62Lexpressing $\mathrm{T}$ cells into lymph nodes. However, the fact that the MECA-79 antibody is efficient at blocking $\mathrm{T}$ cell trafficking into lymph nodes (30) suggests that sulfated core $1 \mathrm{O}$-glycans are the primary ligands for CD62L, but in their absence, other glycan types decorated with sulfated $\operatorname{sLe}^{\mathrm{x}}$ can facilitate the capture of naive T cells on HEVs.

Lymphatic linkage between peripheral tissues and draining lymph nodes is essential for maintaining HEVs and overall lymph node integrity (54-56). Thus, the vascular endothelial cells that comprise HEVs are not intrinsically programmed to express the adhesion molecules and glycosyltransferase enzymes that generate CD62L ligands, but require extrinsic cellular and/ or microenvironmental factors. It has been known for several years that lymphotoxin- $\alpha$ and the lymphotoxin $\beta$ receptor are critical for the development of mature, functional lymph nodes $(57,58)$. Recently, it has now been uncovered that dendritic cells are the cellular source of lymphotoxin for maintaining HEVs in peripheral lymph nodes and depletion of $\mathrm{CD} 11 \mathrm{c}^{+}$dendritic cells results in a loss of MECA-79 reactivity, decreased size and cellularity of peripheral lymph nodes, and impaired homing of naive T cells (59). Lymphotoxin $\alpha$ from $\mathrm{CD}_{11 c^{+}}$dendritic cells that have migrated with the afferent lymph to the draining lymph node stimulate the expression of Fut7, GlcNAc6ST-2, and GlyCAM on HEVs, but interestingly, does not regulate the expression of other adhesion molecules such as ICAM-1, CD31, or VE-cadherin.

Because $\mathrm{CD} 11 \mathrm{c}^{+}$dendritic cells stimulate lymph node endothelial vessels to express sulfated sLe ${ }^{x}$ suggests that HEVlike structures could potentially form in other tissues besides 
lymph nodes depending on the local inflammatory context. In fact, HEV-like structures (as defined by reacting with MECA79) that form in non-lymphoid tissues are often referred to as tertiary lymphoid tissue or mucosa-associated lymphoid tissue (60). Tertiary lymphoid structures have received considerable attention in recent years, particularly in the field of cancer immunology, where these structures may support tumor-specific T cell activation and their presence is generally predictive of favorable treatment outcome $(61,62)$. Thus, the synthesis of sulfated core $1 \mathrm{O}$-glycans can occur in tissues besides lymph nodes and could regulate the trafficking and potentially the activation of CD62L-expressing $\mathrm{T}$ cells during local inflammatory events in non-lymphoid tissue.

\section{T CELL ACTIVATION STIMULATES CORE 2 O-GLYCAN SYNTHESIS}

Naive T cells cannot synthesize core $2 \mathrm{O}$-glycans or bind to $\mathrm{P}$ - and E-selectin, which essentially excludes them from entering nonlymphoid tissues. Following stimulation of the $\mathrm{T}$ cell receptor, both $\mathrm{CD}^{+}$and $\mathrm{CD}^{+} \mathrm{T}$ cells increase expression of Gcnt1, Fut7, and likely additional enzymes that facilitate core $2 \mathrm{O}$-glycan synthesis (Figure 1). This post-translational modification transforms surface proteins such as PSGL-1 and CD43 into P- and E-selectin ligands to direct extravasation across activated vascular endothelium and into non-lymphoid tissues. Although T cell migration is thought to be largely dictated by O-glycan modifications on selectin ligands, in neutrophils, N-linked glycosylation of both CD44 and ESL-1 has been shown to contribute to E-selectin ligand formation $(63,64)$. Even though the formation of P- and E-selectin ligands on $\mathrm{T}$ cells may not be completely dependent on O-glycan synthesis, the cellular source of the glycosylation for $\mathrm{T}$ cells to traffic into non-lymphoid tissue is the opposite of that needed by naive and $\mathrm{T}_{\mathrm{CM}} \mathrm{T}$ cells to home into lymph nodes. Specifically, naive and $\mathrm{T}_{\mathrm{CM}} \mathrm{T}$ cells require CD62L ligands to be synthesized on HEVs, whereas synthesis of complex core 2 O-linked glycans on both effector and memory $\mathrm{T}$ cells dictates the capacity for these cells to be captured by P- and/or E-selectin to initiate the extravasation process and ultimately infiltrate nonlymphoid tissues (Figure 3).

Following activation, most effector $\mathrm{CD}^{+} \mathrm{T}$ cells express Gcnt1, core $2 \mathrm{O}$-glycans, and generate $\mathrm{P}$ - and E-selectin ligands. A number of in vitro studies of $\mathrm{CD} 8^{+} \mathrm{T}$ cell activation have shown that cytokines such as IL-2 and IL-12 can stimulate further P-selectin binding activity $(65,66)$. However, in a model of autoimmunity, where TCR-transgenic $\mathrm{CD} 8^{+} \mathrm{T}$ cells from female mice specific for the male HY-antigen are transferred into male mice, IL-2, -12, and -15 were all dispensable for the formation of P-selectin ligands (67), arguing that antigen recognition may be sufficient to stimulate core $2 \mathrm{O}$-glycan synthesis in $\mathrm{CD} 8^{+} \mathrm{T}$ cells. Whether these cytokines contribute to P-selectin ligand formation on antigen-specific $\mathrm{CD}^{+} \mathrm{T}$ cells responding to active viral or bacterial infection has not been examined in detail. Core $2 \mathrm{O}$-glycan synthesis is regulated primarily by C2GlcNAcT-I in $\mathrm{CD}^{+}$ T cells, but C2GlcNAcT-III may also contribute (68). Following activation, effector $\mathrm{CD}^{+} \mathrm{T}$ cells increase reactivity to PNA (69), demonstrating that the process of $\mathrm{CD}^{+} \mathrm{T}$ cell activation results in decreased capping of the $\alpha 2,3$-linked sialic acid on
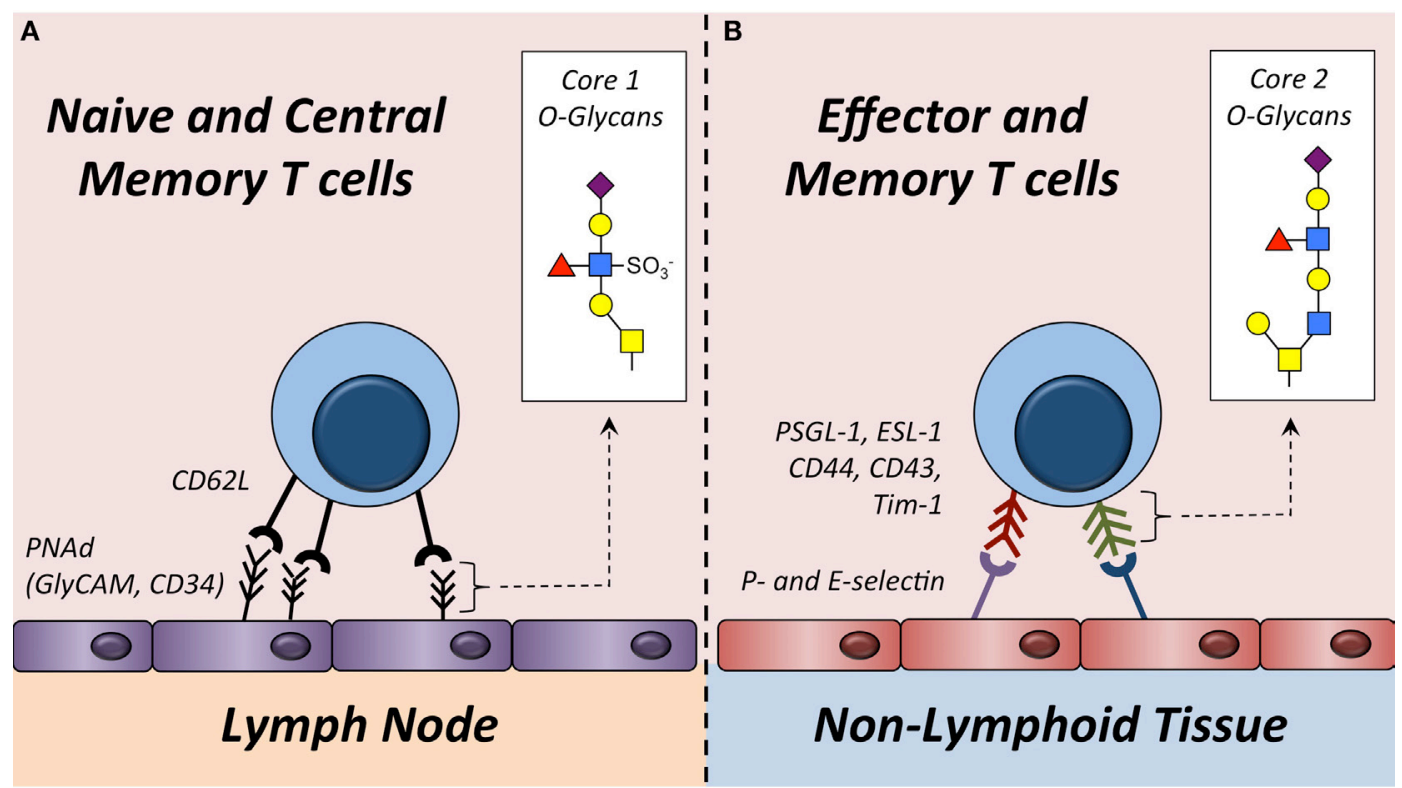

FIGURE 3 | Trafficking of T cells into lymph nodes or non-lymphoid tissue is regulated by O-glycan synthesis. (A) Naive and some memory T cells express L-selectin (CD62L). This serves as the receptor for ligands (e.g., GlyCAM-1, CD34, etc.) expressing sulfated core 1 O-glycans in the high endothelial venules of lymph nodes. Sulfated core $1 \mathrm{O}$-glycans are collectively referred to as peripheral node addressins (PNAd). (B) Effector and some memory $T$ cells synthesize core 2 O-glycans on surface proteins including PSGL-1 and CD43. These modified proteins function as P-and/or E-selectin ligands that facilitate capture of these T cells on activated vascular endothelium to initiate extravasation into non-lymphoid tissues. Enzymes required to synthesize core 1 and core 2 O-glycans are described in Figure 1 and Table 1. 
core 1 O-glycans (Figure 2). Because ST3Gal-I and C2GlcNAcT-I compete for the same core $1 \mathrm{O}$-glycan substrate $(21,70)$, this change in core $1 \mathrm{O}$-glycosylation status could be because of increased C2GlcNAcT-I expression, suppressed ST3Gal-I expression, or perhaps both. Notably, most $\mathrm{St}_{3 \mathrm{gal1}}{ }^{-1-}$ naive $\mathrm{CD} 8^{+} \mathrm{T}$ cells do not survive in the periphery (21), demonstrating that O-linked glycosylation plays important roles in $\mathrm{T}$ cell biology beyond regulating their trafficking potentials.

In contrast to cytotoxic $\mathrm{CD}^{+} \mathrm{T}$ cells, $\mathrm{CD} 4^{+} \mathrm{T}$ cells can be polarized in vitro and in vivo to become T-helper (Th)1, Th2, Th17 or FoxP3 ${ }^{+}$regulatory $\mathrm{T}$ cells (Treg). The collective agreement from a number of studies suggest that Th1 $\mathrm{CD}^{+} \mathrm{T}$ cells differentiated with IL-12 express P-selectin ligands and, to a lesser extent, E-selectin ligands, whereas Th2 $\mathrm{CD}^{+} \mathrm{T}$ cells generated with IL-4 do not. Mechanistically, the transcription factors T-bet and STAT4 (which is activated by IL-12) drive the expression of Gcnt1 and stimulates the synthesis of P-selectin ligands (71). Interestingly, it has been reported that E-selectin ligand formation on Th1 $\mathrm{CD} 4^{+} \mathrm{T}$ cells does not require Gcnt1, suggesting that $\mathrm{CD}^{+} \mathrm{T}$ cells may generate E-selectin ligands independent of core $2 \mathrm{O}$-glycan synthesis (72). Besides IL-12, a number of other inflammatory cytokines may also influence the generation of $\mathrm{P}$ and E-selectin ligands on CD4 ${ }^{+}$T cells. In vitro, IL-18, IL-27, IL-9, IL-25, and TGF- $\beta 1$ all stimulate expression of Gcnt1 and Fut7 in a p38-dependent manner (73). Importantly, activation of the MAPK p38 by these cytokines requires concurrent TCR stimulation, further supporting the concept that an antigen encounter is critical to allow a previously naive $\mathrm{T}$ cell to begin synthesizing core $2 \mathrm{O}$-glycans.

In recent years, a number of additional $\mathrm{CD}^{+} \mathrm{T}$ cell lineages have been characterized, which has expanded our understanding of helper $\mathrm{T}$ cell biology beyond the classical Th1/Th2 differentiation paradigm. CD4 ${ }^{+} \mathrm{T}$ cells activated in the presence of TGF- $\beta$ and IL- 6 become IL-17-producing Th17 cells, which are critical for mucosal host defense, but have also been implicated in causing aberrant immunopathology in the skin and gut (74). A recent study showed that Th17 $\mathrm{CD} 4^{+} \mathrm{T}$ cells synthesize E-selectin ligands better than Th1 $\mathrm{CD}^{+} \mathrm{T}$ cells (75), which is consistent with the observation that Th17 cells are often found in non-lymphoid tissue. However, the fundamental glycobiology (e.g., N-linked vs. O-linked, core 1 vs. core 2, etc.) facilitating E-selectin ligand synthesis of TGF- $\beta$ and IL- 6 differentiated Th17 $\mathrm{CD}^{+} \mathrm{T}$ cells has not been defined. The regulation of core 2 O-glycan synthesis in $\mathrm{CD}^{+}$Tregs also remains largely unexplored, although it has recently been reported that Tregs bearing sLe $^{\mathrm{x}}$ are the most suppressive Treg "subset" found in humans (76). This interesting finding suggests that the tissue homing potential may be directly related to Treg function and that the capacity for these cells to traffic into non-lymphoid tissue may be necessary for their ability to suppress ongoing immune responses. Overall, these studies conclude that TCR-mediated activation is essential for allowing previously naive $\mathrm{T}$ cells to begin synthesizing core $2 \mathrm{O}$-glycans, but that a variety of cytokines and the process of Th-differentiation is critical for shaping the transcriptional activity of specific glycosyltransferase genes that ultimately control $\mathrm{P}$ - and E-selectin ligand formation.

\section{TRAFFICKING OF T CELLS INTO NON-LYMPHOID TISSUES}

P- and E-selectin ligands that are synthesized on recently activated $\mathrm{T}$ cells have been shown to regulate their trafficking into a variety of non-lymphoid tissues during inflammatory challenges. Infiltration of the skin, in particular, relies heavily on the expression of P- and E-selectin ligands (77-79), but expression of these ligands has also been implicated in controlling $\mathrm{T}$ cell trafficking into other anatomical sites including the lung, peritoneal cavity, and the intestinal lamina propria (80-82). Consistent with the observation that IL-12 favors P- and E-selectin ligand synthesis more favorably than IL-4, Th1 CD4 ${ }^{+} \mathrm{T}$ cells traffic into the skin better than Th2 polarized cells $(8,83)$. As mentioned previously, PSGL-1 can function as both a P- and E-selectin ligand and its capacity to bind E-selectin regulates skin homing of Th1 CD4 ${ }^{+}$ $\mathrm{T}$ cells (78). In contrast, CD43 becomes the dominant E-selectin ligand on Th17 CD4 ${ }^{+} \mathrm{T}$ cells (84). CD43 can also function as an E-selectin ligand in human T cells (85), but whether CD43 and PSGL-1 functioning as E-selectin ligands can be used to discriminate between Th17 and Th1 $\mathrm{CD}^{+} \mathrm{T}$ cells in either humans or mice has not been determined.

Several studies have suggested that the route of infection or vaccination will influence the trafficking potential of $\mathrm{T}$ cells following activation, a concept often referred to as "imprinting." For example, $\mathrm{CD}^{+} \mathrm{T}$ cells activated in the draining lymph node following infection of the skin with Vaccinia virus begin synthesizing P- and E-selectin ligands, whereas the same antigenspecific $\mathrm{CD}^{+} \mathrm{T}$ cells activated in mesenteric lymph nodes when Vaccinia virus is delivered by intraperitoneal injection do not (86). Rather, this latter route of infection causes expression of the $\alpha_{4} \beta_{7}$ integrin, which is generally considered to be critical for $\mathrm{T}$ cell homing to the gut. Dendritic cell-based vaccination strategies delivered either into the skin or intravenously have yielded similar findings (87). Mechanistically, production of the vitamin A metabolite, retinoic acid, by intestinal dendritic cells is able to actively suppress the synthesis of P- and E-selectin ligands during $\mathrm{T}$ cell activation, whereas dendritic cells from skin draining lymph nodes do not synthesize this metabolite (88-90). In CD4 ${ }^{+}$ $\mathrm{T}$ cells, retinoic acid was shown to cause the promoter region of Fut7 to remain methylated, thereby suppressing expression of this gene during $T$ cell activation (91). Thus, understanding how different pathogens, routes of vaccination, or specific dendritic cell populations influence $\mathrm{O}$-glycan synthesis and the trafficking potential of effector and memory $\mathrm{T}$ cell populations is critically important for the future development of rational vaccine designs.

In contrast to recently activated effector T cells, most memory $\mathrm{CD}^{+}$and $\mathrm{CD} 4^{+} \mathrm{T}$ cells do not actively synthesize core $2 \mathrm{O}$-glycans, which may limit their capacity to leave the circulation during homeostatic, non-inflammatory conditions. However, it has been appreciated for some time now that memory $\mathrm{CD}^{+} \mathrm{T}$ cells (and perhaps memory $\mathrm{CD} 4^{+} \mathrm{T}$ cells) acquire a promiscuous trafficking potential that allows them to traffic directly into areas of inflammation or tissue injury independent of antigen specificity or re-priming (92). We have recently shown that the memory $\mathrm{CD}^{+}$ $\mathrm{T}$ cells that traffic into the lung or skin following inflammatory 
challenge or viral infection express core $2 \mathrm{O}$-glycans and that blocking $\mathrm{P}$ - and E-selectin prevents memory $\mathrm{CD}^{+} \mathrm{T}$ cells from trafficking into the inflamed skin (93). Memory $\mathrm{CD}^{+} \mathrm{T}$ cells exhibit an "open" epigenetic signature at the Gcnt1 promoter and IL-15 (and potentially other cytokines that activate the STAT5 transcription factor) is sufficient to stimulate core $2 \mathrm{O}$-glycan synthesis, thereby allowing circulating memory $\mathrm{CD}^{+} \mathrm{T}$ cells to traffic into a site of infection without needing to be reactivated by professional antigen-presenting cells. This feature of memory $\mathrm{CD}^{+} \mathrm{T}$ cells contributes significantly to their ability to provide protective immunity against infections in non-lymphoid tissues. Whether core $2 \mathrm{O}$-glycan synthesis is regulated in a similar manner in memory $\mathrm{CD} 4^{+} \mathrm{T}$ cells has not been defined. Thus, these findings demonstrate that $\mathrm{O}$-glycan synthesis can be activated and is highly dynamic in memory $\mathrm{CD}^{+} \mathrm{T}$ cells and that factors apart from antigen recognition control their tissue trafficking potential.

\section{CONCLUSION AND FUTURE DIRECTIONS}

The synthesis of complex O-glycans plays an indispensable role in regulating the trafficking of nearly every $\mathrm{T}$ cell type and subset in vivo, but the complexity of studying these forms of posttranslational modifications and lack of reliable and highly-specific reagents to monitor glycosylation status of cells or individual proteins has limited the progress of this field. Furthermore, the requirement for individual enzymes or proteins that function as selectin ligands to initiate extravasation and tissue homing have been studied most rigorously in neutrophils, not antigen-specific $\mathrm{T}$ cells. For example, it has not been determined if proteins such as CD44 and ESL-1 utilize primarily $\mathrm{N}$ - or O-glycans to function as E-selectin ligands in effector or memory $\mathrm{T}$ cell populations or if expression of these proteins impacts trafficking potentials. In addition, many of the studies identifying how $\mathrm{O}$-glycan synthesis is stimulated on $\mathrm{T}$ cells have relied on in vitro activation strategies. Clearly, these reductionist approaches have strengthened our understanding of how diverse cytokines control the formation of $\mathrm{P}$ - and E-selectin ligands, but how these pathways are integrated in vivo during active infections or following vaccination is less understood.

As we and others have shown, the capacity for memory $\mathrm{T}$ cells to rapidly traffic into a site of infection is critical for protective immunity and is highly dependent on de novo core $2 \mathrm{O}$-glycan synthesis. With regards to rational vaccine design, the process of imprinting memory $\mathrm{T}$ cell populations to home to a specific

\section{REFERENCES}

1. Marth JD, Grewal PK. Mammalian glycosylation in immunity. Nat Rev Immunol (2008) 8:874-87. doi:10.1038/nri2417

2. Ley K, Kansas GS. Selectins in T-cell recruitment to non-lymphoid tissues and sites of inflammation. Nat Rev Immunol (2004) 4:325-35. doi:10.1038/ nri1351

3. Sperandio M, Gleissner CA, Ley K. Glycosylation in immune cell trafficking. Immunol Rev (2009) 230:97-113. doi:10.1111/j.1600-065X.2009. 00795.x

4. Bevilacqua MP. Endothelial-leukocyte adhesion molecules. Annu Rev Immunol (1993) 11:767-804. doi:10.1146/annurev.immunol.11.1.767 tissue microenvironment may be essential to generate functional memory $\mathrm{T}$ cells that are able to provide rapid and robust protective immunity. However, if and how diverse memory $\mathrm{CD}^{+}$ and $\mathrm{CD}^{+} \mathrm{T}$ cell subsets (e.g., $\mathrm{T}_{\mathrm{CM}}$ vs. $\mathrm{T}_{\mathrm{EM}}$ ) or lineages (e.g., Th1 vs. Th17) regulate their O-glycan synthesis machinery in vivo remains mostly unexplored. Recently, a distinct lineage of tissue-resident memory $\left(\mathrm{T}_{\mathrm{RM}}\right) \mathrm{CD}^{+} \mathrm{T}$ cells has been identified that is maintained for extended periods of time in non-lymphoid tissues. Not surprisingly, the formation of P- and E-selectin ligands is required to seed $\mathrm{T}_{\mathrm{RM}}$ precursors in the skin during a viral infection (94). Interestingly, however, it was also reported that tissue-resident memory $\mathrm{CD}^{+} \mathrm{T}$ cells continue to synthesize $\mathrm{E}$ - and P-selectin ligands after they have established residency in the tissue microenvironment. The functional relevance for this is currently unknown, as it is not believed that this subset of memory $\mathrm{CD}^{+} \mathrm{T}$ cells ever re-enters the circulation. This suggests the possibility that the synthesis of $\mathrm{O}$ - and/or N-glycans by $\mathrm{T}_{\mathrm{RM}}$ $\mathrm{CD}^{+} \mathrm{T}$ cells may be required for other biological functions in non-lymphoid tissues that have yet to be described. Finally, how $\mathrm{O}$-glycan synthesis is regulated on antigen-specific T cells during either chronic infections or cancer has not been addressed. The latter, in particular, is of considerable interest clinically, as infiltration of $\mathrm{CD}^{+} \mathrm{T}$ cells into the tumor microenvironment is one of the most promising biomarkers associated with clinical response following immunotherapy. Thus, the therapeutic stimulation of core $2 \mathrm{O}$-glycans on tumor-specific $\mathrm{T}$ cells could be an attractive target for the rational design of combination therapies to enhance $\mathrm{T}$ cell trafficking and ultimately improve cancer immunotherapy techniques. Overall, the studies and findings described here highlight the importance of O-glycan synthesis in regulating the trafficking of essentially every type of $\mathrm{T}$ cell, and thus, deeper mechanistic understandings of this process could lead to advances in therapeutic interventions to either enhance or inhibit the activation and tissue infiltration of both protective (for pathogens and tumors) or pathogenic (for autoimmune or inflammatory disorders) antigen-specific T cells.

\section{AUTHOR CONTRIBUTIONS}

Both authors contributed equally to the writing of this review.

\section{FUNDING}

This work was sponsored by NIH grant K22-AI102981 to JN and $\mathrm{NIH}$ training grant T32-GM071338 to SH.

5. Gotsch U, Jäger U, Dominis M, Vestweber D. Expression of p-selectin on endothelial cells is upregulated by LPS and TNF- $\alpha$ in vivo. Cell Adhes Commun (1994) 2:7-14.

6. Vestweber D, Blanks JE. Mechanisms that regulate the function of the selectins and their ligands. Physiol Rev (1999) 79:181-213.

7. Arbones ML, Ord DC, Ley K, Ratech H, Maynard-Curry C, Otten G, et al. Lymphocyte homing and leukocyte rolling and migration are impaired in L-selectin-deficient mice. Immunity (1994) 1:247-60. doi:10.1016/ 1074-7613(94)90076-0

8. Austrup F, Vestweber D, Borges E, Lohning M, Brauer R, Herz U, et al. P- and E-selectin mediate recruitment of T-helper-1 but not T-helper-2 cells into inflammed tissues. Nature (1997) 385:81-3. doi:10.1038/385081a0 
9. Carlow DA, Gossens K, Naus S, Veerman KM, Seo W, Ziltener HJ. PSGL-1 function in immunity and steady state homeostasis. Immunol Rev (2009) 230:75-96. doi:10.1111/j.1600-065X.2009.00797.x

10. Angiari S, Donnarumma T, Rossi B, Dusi S, Pietronigro E, Zenaro E, et al. TIM-1 glycoprotein binds the adhesion receptor P-selectin and mediates T cell trafficking during inflammation and autoimmunity. Immunity (2014) 40:542-53. doi:10.1016/j.immuni.2014.03.004

11. Sperandio M. Selectins and glycosyltransferases in leukocyte rolling in vivo. FEBS J (2006) 273:4377-89. doi:10.1111/j.1742-4658.2006.05437.x

12. Moody AM, North SJ, Reinhold B, Van Dyken SJ, Rogers ME, Panico M, et al. Sialic acid capping of CD8beta core 1-O-glycans controls thymocyte-major histocompatibility complex class I interaction. J Biol Chem (2003) 278:7240-6. doi:10.1074/jbc.M210468200

13. Van Dyken SJ, Green RS, Marth JD. Structural and mechanistic features of protein O glycosylation linked to CD8+ T-cell apoptosis. Mol Cell Biol (2007) 27:1096-111. doi:10.1128/MCB.01750-06

14. Suzuki H, Raska M, Yamada K, Moldoveanu Z, Julian BA, Wyatt RJ, et al. Cytokines alter IgA1 O-glycosylation by dysregulating C1GalT1 and ST6GalNAc-II enzymes. J Biol Chem (2014) 289:5330-9. doi:10.1074/jbc. M113.512277

15. Ellies LG, Tsuboi S, Petryniak B, Lowe JB, Fukuda M, Marth JD. Core 2 oligosaccharide biosynthesis distinguishes between selectin ligands essential for leukocyte homing and inflammation. Immunity (1998) 9:881-90. doi:10.1016/ S1074-7613(00)80653-6

16. Maly P, Thall A, Petryniak B, Rogers CE, Smith PL, Marks RM, et al. The alpha(1,3)fucosyltransferase Fuc-TVII controls leukocyte trafficking through an essential role in L-, E-, and P-selectin ligand biosynthesis. Cell (1996) 86:643-53. doi:10.1016/S0092-8674(00)80137-3

17. Homeister JW, Thall AD, Petryniak B, Maly P, Rogers CE, Smith PL, et al. The alpha(1,3)fucosyltransferases FucT-IV and FucT-VII exert collaborative control over selectin-dependent leukocyte recruitment and lymphocyte homing. Immunity (2001) 15:115-26. doi:10.1016/S1074-7613(01)00166-2

18. Ellies LG, Sperandio M, Underhill GH, Yousif J, Smith M, Priatel JJ, et al. Sialyltransferase specificity in selectin ligand formation. Blood (2002) 100:3618-25. doi:10.1182/blood-2002-04-1007

19. Yang WH, Nussbaum C, Grewal PK, Marth JD, Sperandio M. Coordinated roles of ST3Gal-VI and ST3Gal-IV sialyltransferases in the synthesis of selectin ligands. Blood (2012) 120:1015-26. doi:10.1182/blood-2012-04424366

20. Yeh JC, Hiraoka N, Petryniak B, Nakayama J, Ellies LG, Rabuka D, et al. Novel sulfated lymphocyte homing receptors and their control by a Core 1 extension beta 1,3-N-acetylglucosaminyltransferase. Cell (2001) 105:957-69. doi:10.1016/S0092-8674(01)00394-4

21. Priatel JJ, Chui D, Hiraoka N, Simmons CJ, Richardson KB, Page DM, et al. The ST3Gal-I sialyltransferase controls CD8+ T lymphocyte homeostasis by modulating O-glycan biosynthesis. Immunity (2000) 12:273-83. doi:10.1016/ S1074-7613(00)80180-6

22. Comelli EM, Head SR, Gilmartin T, Whisenant T, Haslam SM, North SJ, et al. A focused microarray approach to functional glycomics: transcriptional regulation of the glycome. Glycobiology (2006) 16:117-31. doi:10.1093/glycob/ cwj048

23. Brockhausen I, Schachter H, Stanley P. O-GalNAc glycans. 2nd ed. In: Varki A, Cummings RD, Esko JD, Freeze HH, Stanley P, Bertozzi CR, et al., editors. Essentials of Glycobiology. NY: Cold Spring Harbor (2009). p. 115-28.

24. Cummings RD, Etzler ME. Antibodies and lectins in glycan analysis. 2nd ed. In: Varki A, Cummings RD, Esko JD, Freeze HH, Stanley P, Bertozzi CR, et al., editors. Essentials of Glycobiology. NY: Cold Spring Harbor (2009). p. 633-48.

25. Bargatze RF, Kurk S, Butcher EC, Jutila MA. Neutrophils roll on adherent neutrophils bound to cytokine-induced endothelial cells via L-selectin on the rolling cells. J Exp Med (1994) 180:1785-92. doi:10.1084/jem.180.5.1785

26. Matsumura K, Higashida K, Ishida H, Hata Y, Yamamoto K, Shigeta M, et al. Carbohydrate binding specificity of a fucose-specific lectin from Aspergillus oryzae: a novel probe for core fucose. J Biol Chem (2007) 282:15700-8. doi:10.1074/jbc.M701195200

27. Geisler C, Jarvis DL. Effective glycoanalysis with Maackia amurensis lectins requires a clear understanding of their binding specificities. Glycobiology (2011) 21:988-93. doi:10.1093/glycob/cwr080
28. Picker LJ, Michie SA, Rott LS, Butcher EC. A unique phenotype of skinassociated lymphocytes in humans. Preferential expression of the HECA-452 epitope by benign and malignant T cells at cutaneous sites. Am J Pathol (1990) 136:1053-68.

29. Berg EL, Yoshino T, Rott LS, Robinson MK, Warnock RA, Kishimoto TK, et al. The cutaneous lymphocyte antigen is a skin lymphocyte homing receptor for the vascular lectin endothelial cell-leukocyte adhesion molecule 1. J Exp Med (1991) 174:1461-6. doi:10.1084/jem.174.6.1461

30. Streeter PR, Rouse BT, Butcher EC. Immunohistologic and functional characterization of a vascular addressin involved in lymphocyte homing into peripheral lymph nodes. J Cell Biol (1988) 107:1853-62. doi:10.1083/jcb.107.5.1853

31. Barran P, Fellinger W, Warren CE, Dennis JW, Ziltener HJ. Modification of CD43 and other lymphocyte O-glycoproteins by core $2 \mathrm{~N}$-acetylglucosaminyltransferase. Glycobiology (1997) 7:129-36. doi:10.1093/glycob/7.1.129

32. Carlow DA, Ardman B, Ziltener HJ. A novel CD8 T cell-restricted CD45RB epitope shared by CD43 is differentially affected by glycosylation. J Immunol (1999) 163:1441-8.

33. Gallatin WM, Weissman IL, Butcher EC. A cell-surface molecule involved in organ-specific homing of lymphocytes. Nature (1983) 304:30-4. doi:10.1038/ 304030a0

34. Bosse R, Vestweber D. Only simultaneous blocking of the L- and P-selectin completely inhibits neutrophil migration into mouse peritoneum. Eur J Immunol (1994) 24:3019-24. doi:10.1002/eji.1830241215

35. Ramos CL, Kunkel EJ, Lawrence MB, Jung U, Vestweber D, Bosse R, et al. Differential effect of E-selectin antibodies on neutrophil rolling and recruitment to inflammatory sites. Blood (1997) 89:3009-18.

36. Norton CR, Rumberger JM, Burns DK, Wolitzky BA. Characterization of murine E-selectin expression in vitro using novel anti-mouse E-selectin monoclonal antibodies. Biochem Biophys Res Commun (1993) 195:250-8. doi:10.1006/bbrc.1993.2037

37. Frenette PS, Denis CV, Weiss L, Jurk K, Subbarao S, Kehrel B, et al. P-Selectin glycoprotein ligand 1 (PSGL-1) is expressed on platelets and can mediate platelet-endothelial interactions in vivo. J Exp Med (2000) 191:1413-22. doi:10.1084/jem.191.8.1413

38. Borges E, Eytner R, Moll T, Steegmaier M, Campbell MA, Ley K, et al. The P-selectin glycoprotein ligand-1 is important for recruitment of neutrophils into inflamed mouse peritoneum. Blood (1997) 90:1934-42.

39. Jones AT, Federsppiel B, Ellies LG, Williams MJ, Burgener R, Duronio V, et al. Characterization of the activation-associated isoform of CD43 on murine T lymphocytes. J Immunol (1994) 153:3426-39.

40. Nolz JC. Molecular mechanisms of CD8 T cell trafficking and localization. Cell Mol Life Sci (2015) 72(13):2461-73. doi:10.1007/s00018-015-1835-0

41. Rossi FM, Corbel SY, Merzaban JS, Carlow DA, Gossens K, Duenas J, et al. Recruitment of adult thymic progenitors is regulated by P-selectin and its ligand PSGL-1. Nat Immunol (2005) 6:626-34. doi:10.1038/ni1203

42. Chen A, Engel P, Tedder TF. Structural requirements regulate endoproteolytic release of the L-selectin (CD62L) adhesion receptor from the cell surface of leukocytes. J Exp Med (1995) 182:519-30. doi:10.1084/jem. 182.2.519

43. Kaech SM, Wherry EJ, Ahmed R. Effector and memory T-cell differentiation: implications for vaccine development. Nat Rev Immunol (2002) 2:251-62. doi: $10.1038 /$ nri778

44. Harty JT, Badovinac VP. Shaping and reshaping CD8+ T-cell memory. Nat Rev Immunol (2008) 8:107-19. doi:10.1038/nri2251

45. MacLeod MK, Kappler JW, Marrack P. Memory CD4 T cells: generation, reactivation and re-assignment. Immunology (2010) 130:10-5. doi:10.1111/j.1365-2567.2010.03260.x

46. Sallusto F, Lenig D, Forster R, Lipp M, Lanzavecchia A. Two subsets of memory $\mathrm{T}$ lymphocytes with distinct homing potentials and effector functions. Nature (1999) 401:708-12. doi:10.1038/44385

47. Wherry EJ, Teichgraber V, Becker TC, Masopust D, Kaech SM, Antia R, et al. Lineage relationship and protective immunity of memory CD8 T cell subsets. Nat Immunol (2003) 4:225-34. doi:10.1038/ni889

48. Nolz JC, Harty JT. Protective capacity of memory CD8+ T cells is dictated by antigen exposure history and nature of the infection. Immunity (2011) 34:781-93. doi:10.1016/j.immuni.2011.03.020

49. Lee M, Kiefel H, Lajevic MD, Macauley MS, Kawashima H, O’Hara E, et al. Transcriptional programs of lymphoid tissue capillary and high endothelium 
reveal control mechanisms for lymphocyte homing. Nat Immunol (2014) 15:982-95. doi:10.1038/ni.2983

50. Mitoma J, Bao X, Petryanik B, Schaerli P, Gauguet JM, Yu SY, et al. Critical functions of $\mathrm{N}$-glycans in L-selectin-mediated lymphocyte homing and recruitment. Nat Immunol (2007) 8:409-18. doi:10.1038/ni1442

51. Hemmerich S, Bistrup A, Singer MS, Van Zante A, Lee JK, Tsay D, et al. Sulfation of L-selectin ligands by an HEV-restricted sulfotransferase regulates lymphocyte homing to lymph nodes. Immunity (2001) 15:237-47. doi:10.1016/ S1074-7613(01)00188-1

52. van Zante A, Gauguet JM, Bistrup A, Tsay D, Von Andrian UH, Rosen SD. Lymphocyte-HEV interactions in lymph nodes of a sulfotransferase-deficient mouse. J Exp Med (2003) 198:1289-300. doi:10.1084/jem.20030057

53. Uchimura K, Kadomatsu K, El-Fasakhany FM, Singer MS, Izawa M, Kannagi R, et al. $\mathrm{N}$-acetylglucosamine 6-O-sulfotransferase-1 regulates expression of L-selectin ligands and lymphocyte homing. J Biol Chem (2004) 279:35001-8. doi:10.1074/jbc.M404456200

54. Hendriks HR, Eestermans IL. Disappearance and reappearance of high endothelial venules and immigrating lymphocytes in lymph nodes deprived of afferent lymphatic vessels: a possible regulatory role of macrophages in lymphocyte migration. Eur J Immunol (1983) 13:663-9. doi:10.1002/ eji.1830130811

55. Mebius RE, Streeter PR, Breve J, Duijvestijn AM, Kraal G. The influence of afferent lymphatic vessel interruption on vascular addressin expression. J Cell Biol (1991) 115:85-95. doi:10.1083/jcb.115.1.85

56. Mebius RE, Dowbenko D, Williams A, Fennie C, Lasky LA, Watson SR. Expression of GlyCAM-1, an endothelial ligand for L-selectin, is affected by afferent lymphatic flow. J Immunol (1993) 151:6769-76.

57. De Togni P, Goellner J, Ruddle NH, Streeter PR, Fick A, Mariathasan S, et al. Abnormal development of peripheral lymphoid organs in mice deficient in lymphotoxin. Science (1994) 264:703-7. doi:10.1126/science.8171322

58. Rennert PD, James D, Mackay F, Browning JL, Hochman PS. Lymph node genesis is induced by signaling through the lymphotoxin beta receptor. Immunity (1998) 9:71-9. doi:10.1016/S1074-7613(00)80589-0

59. Moussion C, Girard JP. Dendritic cells control lymphocyte entry to lymph nodes through high endothelial venules. Nature (2011) 479:542-6. doi:10.1038/nature 10540

60. Neyt K, Perros F, Geurtsvankessel CH, Hammad H, Lambrecht BN. Tertiary lymphoid organs in infection and autoimmunity. Trends Immunol (2012) 33:297-305. doi:10.1016/j.it.2012.04.006

61. Martinet L, Garrido I, Filleron T, Le Guellec S, Bellard E, Fournie JJ, et al. Human solid tumors contain high endothelial venules: association with T- and B-lymphocyte infiltration and favorable prognosis in breast cancer. Cancer Res (2011) 71:5678-87. doi:10.1158/0008-5472.CAN-11-0431

62. Martinet L, Filleron T, Le Guellec S, Rochaix P, Garrido I, Girard JP. High endothelial venule blood vessels for tumor-infiltrating lymphocytes are associated with lymphotoxin beta-producing dendritic cells in human breast cancer. J Immunol (2013) 191:2001-8. doi:10.4049/jimmunol.1300872

63. Katayama Y, Hidalgo A, Chang J, Peired A, Frenette PS. CD44 is a physiological E-selectin ligand on neutrophils. J Exp Med (2005) 201:1183-9. doi:10.1084/ jem.20042014

64. Yago T, Fu J, Mcdaniel JM, Miner JJ, Mcever RP, Xia L. Core 1-derived O-glycans are essential E-selectin ligands on neutrophils. Proc Natl Acad Sci U S A (2010) 107:9204-9. doi:10.1073/pnas.1003110107

65. Carlow DA, Corbel SY, Williams MJ, Ziltener HJ. IL-2, -4, and -15 differentially regulate $\mathrm{O}$-glycan branching and P-selectin ligand formation in activated CD8 T cells. J Immunol (2001) 167:6841-8. doi:10.4049/jimmunol.167. 12.6841

66. Manjunath N, Shankar P, Wan J, Weninger W, Crowley MA, Hieshima K, et al. Effector differentiation is not prerequisite for generation of memory cytotoxic T lymphocytes. J Clin Invest (2001) 108:871-8. doi:10.1172/JCI13296

67. Carlow DA, Williams MJ, Ziltener HJ. Inducing P-selectin ligand formation in CD8 T cells: IL-2 and IL-12 are active in vitro but not required in vivo. J Immunol (2005) 174:3959-66. doi:10.4049/jimmunol.174.7.3959

68. Merzaban JS, Zuccolo J, Corbel SY, Williams MJ, Ziltener HJ. An alternate core 2 betal,6-N-acetylglucosaminyltransferase selectively contributes to P-selectin ligand formation in activated CD8 T cells. J Immunol (2005) 174:4051-9. doi:10.4049/jimmunol.174.7.4051
69. Galvan M, Murali-Krishna K, Ming LL, Baum L, Ahmed R. Alterations in cell surface carbohydrates on $\mathrm{T}$ cells from virally infected mice can distinguish effector/memory CD8+ T cells from naive cells. J Immunol (1998) 161:641-8.

70. Schachter H, Brockhausen I. The biosynthesis of branched O-glycans. Symp Soc Exp Biol (1989) 43:1-26.

71. Lim YC, Xie H, Come CE, Alexander SI, Grusby MJ, Lichtman AH, et al. IL-12, STAT4-dependent up-regulation of CD4(+) T cell core 2 beta-1,6-n-acetylglucosaminyltransferase, an enzyme essential for biosynthesis of P-selectin ligands. J Immunol (2001) 167:4476-84. doi:10.4049/ jimmunol.167.8.4476

72. Snapp KR, Heitzig CE, Ellies LG, Marth JD, Kansas GS. Differential requirements for the O-linked branching enzyme core 2 betal-6-N-glucosaminyltransferase in biosynthesis of ligands for E-selectin and P-selectin. Blood (2001) 97:3806-11. doi:10.1182/blood.V97.12.3806

73. Ebel ME, Awe O, Kaplan MH, Kansas GS. Diverse inflammatory cytokines induce selectin ligand expression on murine $\mathrm{CD} 4 \mathrm{~T}$ cells via p38alpha MAPK. J Immunol (2015) 194:5781-8. doi:10.4049/jimmunol.1500485

74. Korn T, Bettelli E, Oukka M, Kuchroo VK. IL-17 and Th17 cells. Annu Rev Immunol (2009) 27:485-517. doi:10.1146/annurev.immunol.021908. 132710

75. Alcaide P, Maganto-Garcia E, Newton G, Travers R, Croce KJ, Bu DX, et al. Difference in Th1 and Th17 lymphocyte adhesion to endothelium. J Immunol (2012) 188:1421-30. doi:10.4049/jimmunol.1101647

76. Miyara M, Chader D, Sage E, Sugiyama D, Nishikawa H, Bouvry D, et al. Sialyl Lewis $\mathrm{x}$ (CD15s) identifies highly differentiated and most suppressive FOXP3high regulatory T cells in humans. Proc Natl Acad Sci U S A (2015) 112:7225-30. doi:10.1073/pnas.1508224112

77. Tietz W, Allemand Y, Borges E, Von Laer D, Hallmann R, Vestweber D, et al. $\mathrm{CD} 4+\mathrm{T}$ cells migrate into inflamed skin only if they express ligands for $\mathrm{E}$ - and P-selectin. J Immunol (1998) 161:963-70.

78. Hirata T, Merrill-Skoloff G, Aab M, Yang J, Furie BC, Furie B. P-Selectin glycoprotein ligand 1 (PSGL-1) is a physiological ligand for E-selectin in mediating T helper 1 lymphocyte migration. J Exp Med (2000) 192:1669-76. doi:10.1084/jem.192.11.1669

79. Hirata T, Furie BC, Furie B. P-, E-, and L-selectin mediate migration of activated CD8+ T lymphocytes into inflamed skin. JImmunol (2002) 169:4307-13. doi:10.4049/jimmunol.169.8.4307

80. Wolber FM, Curtis JL, Maly P, Kelly RJ, Smith P, Yednock TA, et al. Endothelial selectins and alpha4 integrins regulate independent pathways of T lymphocyte recruitment in the pulmonary immune response. J Immunol (1998) 161:4396-403.

81. Xie H, Lim YC, Luscinskas FW, Lichtman AH. Acquisition of selectin binding and peripheral homing properties by $\mathrm{CD} 4(+)$ and $\mathrm{CD} 8(+) \mathrm{T}$ cells. J Exp Med (1999) 189:1765-76. doi:10.1084/jem.189.11.1765

82. Haddad W, Cooper CJ, Zhang Z, Brown JB, Zhu Y, Issekutz A, et al. P-selectin and P-selectin glycoprotein ligand 1 are major determinants for Th1 cell recruitment to nonlymphoid effector sites in the intestinal lamina propria. J Exp Med (2003) 198:369-77. doi:10.1084/jem.20020691

83. Borges E, Tietz W, Steegmaier M, Moll T, Hallmann R, Hamann A, et al. P-selectin glycoprotein ligand-1 (PSGL-1) on T helper 1 but not on T helper 2 cells binds to P-selectin and supports migration into inflamed skin.J Exp Med (1997) 185:573-8. doi:10.1084/jem.185.3.573

84. Velazquez F, Grodecki-Pena A, Knapp A, Salvador AM, Nevers T, Croce KJ, et al. CD43 functions as an E-selectin ligand for Th17 cells in vitro and is required for rolling on the vascular endothelium and Th17 cell recruitment during inflammation in vivo. J Immunol (2016) 196:1305-16. doi:10.4049/ jimmunol.1501171

85. Fuhlbrigge RC, King SL, Sackstein R, Kupper TS. CD43 is a ligand for E-selectin on CLA+ human T cells. Blood (2006) 107:1421-6. doi:10.1182/ blood-2005-05-2112

86. Liu L, Fuhlbrigge RC, Karibian K, Tian T, Kupper TS. Dynamic programming of CD8+ T cell trafficking after live viral immunization. Immunity (2006) 25:511-20. doi:10.1016/j.immuni.2006.06.019

87. Dudda JC, Simon JC, Martin S. Dendritic cell immunization route determines CD8+ T cell trafficking to inflamed skin: role for tissue microenvironment and dendritic cells in establishment of T cell-homing subsets. J Immunol (2004) 172:857-63. doi:10.4049/jimmunol.172.2.857 
88. Iwata M, Hirakiyama A, Eshima Y, Kagechika H, Kato C, Song SY. Retinoic acid imprints gut-homing specificity on T cells. Immunity (2004) 21:527-38. doi:10.1016/j.immuni.2004.08.011

89. Mora JR, Cheng G, Picarella D, Briskin M, Buchanan N, Von Andrian UH. Reciprocal and dynamic control of CD8 T cell homing by dendritic cells from skin- and gut-associated lymphoid tissues. J Exp Med (2005) 201:303-16. doi:10.1084/jem.20041645

90. Edele F, Molenaar R, Gutle D, Dudda JC, Jakob T, Homey B, et al. Cutting edge: instructive role of peripheral tissue cells in the imprinting of $\mathrm{T}$ cell homing receptor patterns. J Immunol (2008) 181:3745-9. doi:10.4049/ jimmunol.181.6.3745

91. Pink M, Ratsch BA, Mardahl M, Durek P, Polansky JK, Karl M, et al. Imprinting of skin/inflammation homing in CD4+ T cells is controlled by DNA methylation within the fucosyltransferase 7 gene. J Immunol (2016) 197:3406-14. doi:10.4049/jimmunol.1502434

92. Woodland DL, Kohlmeier JE. Migration, maintenance and recall of memory T cells in peripheral tissues. Nat Rev Immunol (2009) 9:153-61. doi:10.1038/ nri2496
93. Nolz JC, Harty JT. IL-15 regulates memory CD8+ T cell O-glycan synthesis and affects trafficking. JClin Invest (2014) 124:1013-26. doi:10.1172/ JCI72039

94. Jiang X, Clark RA, Liu L, Wagers AJ, Fuhlbrigge RC, Kupper TS. Skin infection generates non-migratory memory CD8+ T(RM) cells providing global skin immunity. Nature (2012) 483:227-31. doi:10.1038/ nature 10851

Conflict of Interest Statement: The authors declare that the research was conducted in the absence of any commercial or financial relationships that could be construed as a potential conflict of interest.

Copyright (C) 2017 Hobbs and Nolz. This is an open-access article distributed under the terms of the Creative Commons Attribution License (CC BY). The use, distribution or reproduction in other forums is permitted, provided the original author(s) or licensor are credited and that the original publication in this journal is cited, in accordance with accepted academic practice. No use, distribution or reproduction is permitted which does not comply with these terms. 